Slađana Pavići ${ }^{1}$ Aleksandra Andrić2, Marija Antić ${ }^{1}$, Milica Jovanović ${ }^{3}$, Aleksa Novković ${ }^{4}$ Aleksandra Pavić ${ }^{4}$

\title{
ETIOLOGIJA, EPIDEMIOLOŠKI I KLINIČKI PARAMETRI INFEKCIJA URINARNOG TRAKTA KOD BOLESNIKA SA DIABETES MELLITUSOM
}

\begin{abstract}
Sažetak: Uvod: Infekcije urinarnog trakta su među najčešćim infekcijama u vanbolničkoj i bolničkoj sredini. Bolesnici oboleli od dijabetesa imaju češće urinarne infekcije, kao i komplikacije ovih infekcija.
\end{abstract}

Cilj istraživanja je bio ispitivanje bakterijskih uzročnika i kliničkog toka bolničkih i vanbolničkih urinarnih infekcija kod bolesnika sa diabetes mellitusom.

Metodi istraživanja: Ispitani su bolesnici sa diabetes mellitus-om lečeni zbog urinarnih infekcija na Odeljenju za infektivne bolesti Opšte bolnice Užice, od januara 2009. do decembra 2018. godine. Prikupljeni su epidemiološki, klinički, biohemijski i mikrobiološki podaci. Bakterijski uzročnici su dokazani zasejavanjem na standardne podloge za rast Gram pozitivnih i Gram negativnih bakterija.

Rezultati: Od ukupno 772 bolesnika sa diabetes mellitusom koji su imali simptomatsku infekciju urinarnog trakta, kod 402 bolesnika urinarna infekcija je nastala u bolničkim uslovima. Od svih ispitanika, $67.7 \%$ su bile žene. Najčešći uzročnici urinarnih infekcija nastalih van bolnice bili su Escherichia coli, Klebsiella sp, Enterococcus (47\%, 31\%, 10\%), a među bolničkim sojevima Klebsiella sp, Escherichia coli, Proteus mirabilis (41\%, 32\%, 9,7\%). Komplikacije (sepsa, urinarna opstrukcija, pijelonefritis) su nastale kod $23.8 \%$ urinarnih infekcija nastalih van bolnice i kod 3,7\% bolničkih infekcija. Plasiran urinarni kateter pre pojave infekcije imalo je $57.8 \%$ bolesnika, od čega $97,8 \%$ onih sa bolničkim poreklom urinarne infekcije.

Zaključak: Najčešći uzročnici infekcije urinarnog trakta bolesnika sa dijabetesom su Escherichia coli i Klebsiella species, u bolničkim i \footnotetext{
sladjanapj@gmail.com

2 Institut za javno zdravlje, Užice, Srbija

3 Institut za infektivne i tropske bolesti, Beograd, Srbija

4 Medicinski fakultet Univerziteta u Beogradu, Beograd, Srbija
}

1 Slađana Pavić, Odeljenje za infektivne i tropske bolesti Opšte bolnice Užice, Užice, Srbija; 
vanbolničkim uslovima. Enterococcus je češći uzročnik vanbolničkih infekcija. Od ove infekcije češće obolevaju žene. Simptomi i komplikacije su prisutniji u slučaju vanbolničke infekcije. Korišćenje urinarnog katetera značajno doprinosi nastanku bolničke urinarne infekcije.

Ključne reči: diabetes mellitus, infekcija urinarnog trakta, etiologija

\begin{abstract}
Introduction: Urinary tract infections are common community-acquried and nasocomial infections. Patients with Diabetes mellitus have more frequent urinary infections and their complications.
\end{abstract}

The aim of the study was to investigate bacterial agents and the clinical course of hospital and community-acquried urinary infections in patients with Diabetes mellitus.

Methods: We examed patients with Diabetes mellitus treated for urinary tract infection at the Department of Infectious Diseases, General Hospital Uzice, from January 2009 to December 2018. We collected epidemiological, clinical, biochemical and microbiological data. Examined urin was set up on agar to detect Gram positive and Gram negative bacteria.

Results: We examined a total of 772 patients with Diabetes mellitus and a symptomatic urinary tract infection. In 402 patients, urinary infection was nasocomial. $67.7 \%$ of patients were women. Escherichia coli, Klebsiella spp. and Enterococcus were the most common causes of community-acquried infection $(47 \%, 31 \%, 10 \%$, respectively). Klebsiella spp, Escherichia coli, Proteus mirabilis (41\%, 32\%, 9.7\%, respectively) were the most common causes of nasocomial infection. Complications (sepsis, urinary obstruction, pyelonephritis) occurred in $23.8 \%$ of community-acquried infections, $3.7 \%$ of hospital infections. Cateterization of the urinary bladder was a risk factor for infection in $57.8 \%$ of patients, of which $97.8 \%$ had nasocomial infection.

Conclusion: The most common causes of urinary tract infection (hospital and community-acquried) are Escherichia coli and Klebsiella species. Enterococcus is a more common cause of community-acquried infections. Infections are more common in women. Patients with community-acquried infections had more symptoms and complications. Urinary catheter use significantly increases the risk of infection.

Key words: Diabetes mellitus, urinary tract infection, etiology

\title{
Uvod
}

Infekcije urinarnog trakta su među najčešćim infekcijama humane populacije, posebno kod žena (1). Klinička slika urinarnih infekcija varira od asimptomatske, do teških kliničkih oblika praćenih komplikacijama, kao što je sepsa i šokno stanje (2). Važan faktor rizika za nastanak urinarnih infekcija je postojanje diabetes mellitusa (3). 
Urinarne infekcije su obično izazvane bakterijama, među kojima je najfrekventnija Escherichia coli. Pored nje, česti uzročnici su i Klebsiella spp, Proteus mirabilis, Pseudomonas aeruginosa, ali i Streptococcus faecalis i Staphylococcus saprophyticus. Poslednja dva navedena uzročnika češća su kod mlađe ženske populacije i povezana sa seksualnom aktivnošću (4). Urinarne infekcije su najčešće nazokomijalne infekcije, sa prevalencijom od $40 \%$ (5). Faktori rizika za njihov nastanak u bolničkoj sredini su plasiranje urinarnog katetera, uvođenje uroloških instrumenata, hirurške intervencije, zloupotreba antibiotika, hronične bubrežne bolesti, diabetes mellitus i transplantacija bubrega (6).

\section{Cilj ispitivanja}

Cilj našeg rada bio je da se ispitaju najčešći bakterijski uzročnici urinarne infekcije kod pacijenata sa diabetes mellitusom, terapijske mogućnosti u zavisnosti od rezistencije uzročnika, klinički tok i faktori rizika za nastanak ove infekcije.

\section{Metodi}

Retrogradno su ispitani bolesnici sa diabetes mellitusom i dijagnostikovanom simptomatskom urinarnom infekcijom, lečeni na Odeljenju za infektivne i tropske bolesti Opšte bolnice Užice, u periodu od januara 2009. do decembra 2018. godine.

Iz ispitivanja su isključeni bolesnici sa bakterijskim ili virusnim koinfekcijama, autoimunim bolestima, teškim hematološkim i malignim bolestima, kao i HIV pozitivni bolesnici.

Ispitane su demografske karakteristike (pol, uzrast), biohemijske analize, klinički tok, pojava komplikacija i faktori rizika. Dijagnoza je potvrđena identifikacijom bakterijskog uzročnika iz urina bolesnika. Urin je zasejavan na standardne podloge za Gram pozitivne i Gram negativne uzročnike koje se koriste u mikrobiološkim laboratorijama u Republici Srbiji. Svim bolesnicima je urađena ultrasonografija urogenitalnog trakta.

\section{Rezultati}

Ispitano je ukupno 772 bolesnika sa diabetes mellitusom koji su imali simptomatsku infekciju urinarnog trakta (infectio tractus urinarii) (ITU). Od ukupnog broja, kod 402 bolesnika urinarna infekcija je nastala nakon prijema u bolnicu.

Demografske karakteristike ispitanika prikazane su u Tabeli 1. 
Tabela 1. Demografske karakteristike bolesnika sa diabetes mellitusom i infekcijom urinarnog trakta

\begin{tabular}{|c|c|c|c|}
\hline Demografske karakteristike & $\begin{array}{c}\text { Vanbolnička ITU } \\
\text { Broj bolesnika (\%) }\end{array}$ & $\begin{array}{c}\text { Bolnička ITU } \\
\text { Broj bolesnika (\%) }\end{array}$ & P \\
\hline Uzrast $\geq 65$ godina & $198(53,5)$ & $325(80,8)$ & 0.124 \\
\hline Pol (ženski) & $310(83,8)$ & $289(71,9)$ & 0.311 \\
\hline
\end{tabular}

$\mathrm{P}$ - statistička značajnost između bolesnika sa vanbolničkom i bolničkom infekcijom prema uzrastu i polu

Uzrast bolesnika sa vanbolničkom infekcijom bio je od 28 do 84 godine (44.6+/-10.4).

Uzrast ispitanika sa bolničkom infekcijom bio je od 44 do 92 godine (58.3+/-11.4).

Nije dokazana statistički značajna razlika među ispitanicima po uzrastu i polu.

Najčešći uzročnici infekcije urinarnog trakta kod naših ispitanika prikazani su u Tabeli 2.

Tabela 2. Uzročnici infekcije urinarnog trakta kod bolesnika sa diabetes mellitusom

\begin{tabular}{|c|c|c|c|}
\hline Uzročnici & $\begin{array}{c}\text { Vanbolnička ITU } \\
\text { Broj bolesnika (\%) }\end{array}$ & $\begin{array}{c}\text { Bolnička ITU } \\
\text { Broj bolesnika (\%) }\end{array}$ & P \\
\hline Escherichia coli & $174(47,0)$ & $129(32,1)$ & 0.212 \\
\hline Klebsiella spp. & $115(31,1)$ & $165(41,0)$ & 0.309 \\
\hline Proteus mirabilis & $18(4,9)$ & $39(9,7)$ & 0.052 \\
\hline Pseudomona aeruginosa & $18(4,9)$ & $31(7,7)$ & 0.112 \\
\hline Enterococcus & $37(10,0)$ & $19(4,7)$ & 0.022 \\
\hline
\end{tabular}

$\mathrm{P}$ - statistička značajnost između bolesnika sa vanbolničkom i bolničkom infekcijom prema vrsti uzročnika

Escherichia coli i Klebsiela spp. bile su najčešći uzročnici. Nije bilo statistički značajne razlike u vrsti uzročnika u odnosu na poreklo infekcije.

U Tabeli 3 prikazani su subjektivni simptomi i laboratorijski nalazi ispitanika.

Tabela 3. Simptomi i laboratorijski nalazi infekcije urinarnog trakta kod bolesnika sa diabetes mellitusom

\begin{tabular}{|c|c|c|c|}
\hline Parametri & $\begin{array}{c}\text { Vanbolnička ITU } \\
\text { Broj bolesnika (\%) }\end{array}$ & $\begin{array}{c}\text { Bolnička ITU } \\
\text { Broj bolesnika (\%) }\end{array}$ & P \\
\hline Slabost/malaksalost & $355(95,9)$ & $168(41,8)$ & 0.028 \\
\hline Urinarne tegobe & $333(90,0)$ & $128(31,8)$ & 0.003 \\
\hline
\end{tabular}




\begin{tabular}{|c|l|l|l|}
\hline Povišena telesna $\mathrm{T}>38 \mathrm{C}$ & $314(84,9)$ & $365(90,8)$ & 0.312 \\
\hline Bol suprapubično/lumbalno & $292(78,9)$ & $285(70,9)$ & 0.332 \\
\hline Leukocitoza $>15 \times 10^{9} / \mathrm{L}$ & $351(94,9)$ & $357(88,8)$ & 0.394 \\
\hline C reaktivni protein $>5 \mathrm{mg} / 1$ & $359(97,0)$ & $398(99,0)$ & 0.506 \\
\hline
\end{tabular}

$\mathrm{P}$ - statistička značajnost između bolesnika sa vanbolničkom i bolničkom infekcijom prema navedenim parametrima

Dobijena je statistički značajna razlika među ispitanicima u pogledu prisustva slabosti i urinarnih tegoba.

Najčešće komplikacije naših ispitanika prikazane su u Tabeli 4.

Tabela 4. Komplikacije infekcije urinarnog trakta kod bolesnika sa diabetes mellitusom

\begin{tabular}{|c|c|c|c|}
\hline Komplikacije & $\begin{array}{c}\text { Vanbolnička ITU } \\
\text { Broj bolesnika (\%) }\end{array}$ & $\begin{array}{c}\text { Bolnička ITU } \\
\text { Broj bolesnika (\%) }\end{array}$ & P \\
\hline Pijelonefritis & $28(7,7)$ & $7(1,7)$ & 0.00 \\
\hline Urinarna opstrukcija & $15(4,1)$ & $3(0,7)$ & 0.00 \\
\hline Sepsa & $45(12,2)$ & $5(1,2)$ & 0.00 \\
\hline
\end{tabular}

$\mathrm{P}$ - statistička značajnost između bolesnika sa vanbolničkom i bolničkom infekcijom prema komplikacijama

Dobijena je statistički značajna razlika u nastanku komplikacija između bolesnika sa bolničkom i vanbolničkom infekcijom.

Faktori rizika za nastanak urinarne infekcije prikazani su u Tabeli 5.

Tabela 5. Faktori rizika za nastanak infekcije urinarnog trakta kod bolesnika sa diabetes mellitusom

\begin{tabular}{|c|c|c|}
\hline Faktori rizika & $\begin{array}{c}\text { Vanbolnička ITU } \\
\text { Broj bolesnika (\%) }\end{array}$ & $\begin{array}{c}\text { Bolnička ITU } \\
\text { Broj bolesnika (\%) }\end{array}$ \\
\hline Kalkuloza bubreg/mokraćna bešika & $263(71,1)$ & $297(73,9)$ \\
\hline Urinarni kateter & $57(15,4)$ & $389(96,8)$ \\
\hline Prethodne urogenitalne intervencije/operacije & $22(5,9)$ & $30(7,5)$ \\
\hline
\end{tabular}

Uočena je statistički značajna razlika u prisustvu urinarnog katetera između ispitivanih grupa $(\mathrm{P}=0.00)$. 


\section{Diskusija}

Pacijenti koji imaju diabetes mellitus češće obolevaju od različitih infekcija, što se objašnjava smanjenjem T-ćelijskog imunog odgovora kod ovih osoba, kao i poremećajem funkcije neutrofila $(7,8)$. Dokazano je da ovi bolesnici imaju povećan rizik i za asimptomatsku i simptomatsku infekciju urinarnog trakta $(9,10)$.

Kao i u pomenutim istraživanjima, i kod nas su žene činile značajnu većinu ispitanika, bez obzira na poreklo infekcije. Ovu razliku u polu objašnjava činjenica da je gojaznost kao važan faktor rizika za nastanak dijabetesa prisutnija kod žena (11). Takođe, infekcije urinarnog trakta češće su opisane kod žena u odnosu na muškarce sa dijabetesom (12). Ima i studija u kojima su takvi pacijenti češće bili muškarci i to je objašnjeno mogućom upalom prostate (13). Navedeni zaključak se odnosio na osobe sa tipom 1 diabetesa. U našem istraživanju nije analizirana razlika u odnosu na tip dijabetesa.

Dobijeni rezultat o većini ispitanika starijeg uzrasta sa dijabetesom u našem istraživanju već su uočili i drugi istraživači (14).

Većina bolesnika je imala izražene opšte simptome uz visoku telesnu temperaturu, pri čemu su bolesnici sa vanbolničkom urinarnom infekcijom imali značajno prisutniju slabost i urinarne tegobe. Ovo je bilo očekivano, s obzirom na to da su navedene tegobe bile razlog da bolesnici sa vanbolničkim infekcijama dođu na lečenje.

Najčešći uzročnici infekcije urinarnog trakta u našoj studiji bili su Escherichia coli i Klebsiella spp, bez značajne razlike u odnosu na poreklo infekcije. Do istog rezultata došli su i drugi istraživači (12). Ronald je, za razliku od naših rezultata, uočio Staphylococcus saprophyticus kao značajan etiološki faktor vanbolničke infekcije urinarnog trakta. Radilo se o ženama mlađe životne dobi i objašnjeno je seksualnom aktivnošću. Navedena ispitivana populacija nije kompatibilna sa našim ispitanicima. Analizirajući uzročnike kod osoba sa diabetes mellitusom, Klebsiella spp, Escherichia coli i Enterococcus su bili najčešći, kao i kod naših pacijenata (15). Enterococcus je kod nas bio značajno češći uzročnik vanbolničke infekcije, što odgovara i pomenutom Ronaldovom istraživanju.

Pacijenti sa bolničkim poreklom infekcije su u značajno većoj meri pre pojave urinarne infekcije nosili urinarni kateter, što je najčešći način unosa infektivnog agensa. Očekivano je da je infekcija nastala u takvim uslovima bila od početka adekvatno lečena, pa su i komplikacije kod ovih pacijenata bile značajno ređe.

\section{Zaključak}

Među bolesnicima sa diabetes mellitusom žene češće obolevaju od infekcije urinarnog trakta, a najčešći uzročnici su Escherichia coli i Klebsiella species, bez obzira da li je u pitanju bolnička, ili vanbolnička infekcija. Enterococcus je češći uzročnik vanbolničkih infekcija urinarnog trakta kod bolesnika sa dijabetesom. Bolesnici sa vanbolničkim poreklom urinarne infekcije imaju više izražene simptome infekcije i češću pojavu komplikacija, posebno sepse. Značajan faktor rizika za bolničku urinarnu infekciju je korišćenje urinarnog katetera, pa bi njegova primena trebalo da bude strogo indikovana. 